\title{
The Effect of Leadership, Supervision and Imposition of Sanctions (Punishment) Against Employee Work Discipline of PT. Charisma Blessing Initiative
}

\author{
Tine Yuliantini ${ }^{1}$ Eri Marlapa ${ }^{2}$ Wahyu Kurniawan $^{3}$ \\ Program S1 Manajemen Falkutas Ekonomi dan Bisinis, Universitas Mercu Buana Jakarta
}

\begin{abstract}
The purpose of the study was to determine the effect of leadership, supervision and sanctions on the work discipline of employees of PT. Kharisma Berkah Intikarsa Bekasi West Java. This research is a qualitative research. This research was conducted at PT. Berkah Intikarsa Bekasi West Java with a total population of 100 employees. The sample in this study was 80 employees using the Solvin formula with a 5\% limit. The technique of data collection is done by questionnaire method. Test the validity and reliability of the product moment correlation formula data from Pearson and Cronbach's Alpha. The data analysis technique used to test the hypothesis is multiple linear regression analysis. Based on the results of data analysis can be concluded, (1) there is a positive and significant influence on leadership towards the work discipline of PT. Kharisma Berkah Intikarsa Bekasi West Java, (2) there is a positive and significant influence on the supervision of the work discipline of employees of PT. Kharisma Berkah Intikarsa Bekasi West Java. (3) There is a positive and significant influence on the sanctioning of the work discipline of the employees of PT. Kharisma Berkah Intikarsa Bekasi West Java.
\end{abstract}

Keywords: Leadership, Supervision, Granting Sanctions and Work Discipline

DOI: $10.7176 / \mathrm{JESD} / 10-20-12$

Publication date:October $31^{\text {st }} 2019$

\section{Introduction}

\section{A. Background}

Business competition continues to increase from time to time as a result of the growth of new competitors from similar products, substitute products, and other products, both coming from within the country and abroad. Human resource management plays a decisive role in the life of an organization, namely how well the organization performs, how well the organization's strategy is carried out, and how far the predetermined goals can be achieved.

Human resources are one element of the organization and have an important role in organizational activities. Therefore human resources must be managed properly so that they can be efficient and effective in achieving the mission and goals of the organization.

At this time human resources are not only limited to workers or employees who work, contribute in an organization, but more than an asset and a very important element in the sustainability of the organization. If the role of human resources provides a positive thing for an organization, it will benefit the organization, but if human resources actually have a negative impact on the organization it will certainly harm the organization.

The most important thing in managing human resources is regarding employee performance. To create high performance, it is necessary to increase optimal work and be able to utilize the potential of human resources owned by employees to create organizational goals, so that it will make a positive contribution to the development of the organization. In addition, organizations need to pay attention to various factors that can affect employee performance, in this case the role of the organization is needed in improving effective and efficient performance, in order to encourage the creation of attitudes and behaviors and professional actions in completing work in accordance with their respective fields and responsibilities respectively.

Discipline is very important in organizational growth, discipline is used as a tool to motivate employees to carry out their work individually or in groups. discipline is the behavior of a person in accordance with regulations, work procedures that exist or discipline is the attitude, behavior, and actions in accordance with the regulations of the organization both written and unwritten Sutrisno (2015: 89). The benefit of discipline is to educate employees to comply with regulations, procedures and existing policies, and carry them out correctly so that they can produce 
good performance. Work discipline is very closely related to one's leadership in an organization that is led. Leaders must reflect the nature of good leadership to set an example for employees.

In upholding discipline, companies need to provide supervisory measures to employees in order to carry out their work as well as possible. Supervision is needed to direct employees to carry out work properly and in accordance with company rules. If in carrying out the work activities of an organization or company without supervision it can lead to decreased work discipline and will directly affect other activities, so that it can hamper the achievement of the goals of an organization or company. Therefore, supervision is needed to produce a positive impact on the company in terms of employee work discipline.

The application of discipline in the company can also be done by giving warnings or sanctions to employees who break the rules. Imposing sanctions on employees may also be in the form of a warning letter, salary deductions, suspension or dismissal. This is done to provide a deterrent effect to employees who are not disciplined and do not take disciplinary action again in the future.

PT. Kharisma Berkah Intikarsa was formed in 2007. The company is engaged in the retail business which is located in Bekasi. Products sold by PT. Kharisma Berkah Intikarsa namely school stationery, office stationery, textbooks \& reading, musical \& sports equipment, school supplies, electronic devices, gifts \& fancy. In the course of business, PT. Kahrisma Berkah Intikarsa cannot be separated from various problems that must be faced.

Problems experienced by PT. Kharisma Berkah Intikarsa is about bad employee work discipline, indicated by the existence of several violations of discipline committed by employees or employees in the company. According to observations made by researchers at PT. Kharisma Berkah Attendance initiative is the main factor in employee discipline.

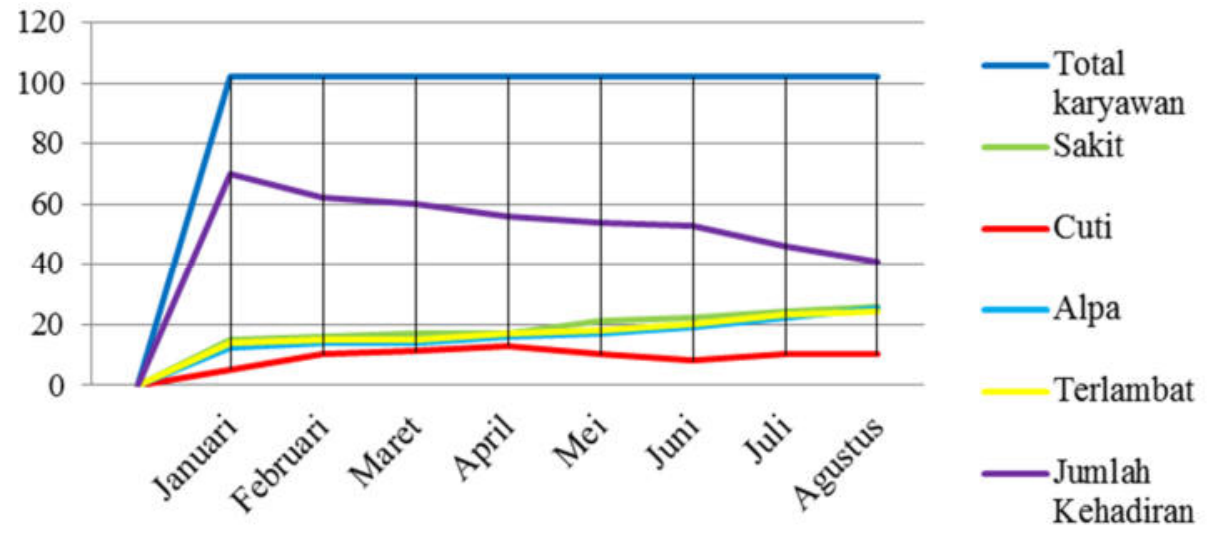

Based on the table above, it can be seen that the number of employees who were absent from absenteeism from January to August 2018 is still high. In addition, many employees are absent due to neglect, there are also employees who are absent due to illness. And it can be seen from the attendance data that there are still many employees who arrive late in January to March 2018, thus it can reduce the effective time of employees while working so that it can affect the performance of daily employees.

In a study conducted by Devita Permatasari (2015) entitled "Analysis of the Effects of Leadership, Supervision, and Imposition of Sanctions on Employee Work Discipline (Study at PT. Citra Yoviana Semarang Branch)" with Leadership, Supervision and Imposition of Sanctions as an independent variable and Work Discipline as a Dependent variable, shows that leadership, supervision and sanctions have a positive and significant effect on work discipline.

\section{B. LITERATURE REVIEW}

\section{Work Discipline}

According Sutrisno (2015: 89) discipline is a person's behavior in accordance with regulations, existing work procedures or discipline is an attitude, behavior, and deeds in accordance with the regulations of the organization 
both written and unwritten. According to Malayu S.P Hasibuan (2017: 193), discipline is one's awareness and willingness to obey all company regulations and applicable social norms. According to Mangkunegara (2015: 127) work discipline is defined as the implementation of management to reinforce organizational guidelines. Based on the expert's explanation of the understanding of work discipline, it can be concluded that work discipline is the awareness and willingness of someone to respect, respect, and obey the rules and regulations and social norms that apply and obey and carry out procedures that apply both in writing and not in writing in an organization or company. Work discipline helps the company or organization in achieving its goals. Without the support of discipline from every employee or employee of course the company will be difficult in achieving and realizing its goals.

\section{Forms of Work Discipline}

According to Mangkunegara (2015: 129) that forms of work discipline are:

1. Preventive Discipline

It is an effort to move employees to follow and comply with work guidelines, the rules that have been outlined by the company.

2. Corrective Discipline

It is an effort to move employees in a regulation and direct it to comply with the rules in accordance with the guidelines that apply to the company.

3. Progressive Discipline

It is an activity that provides more severe penalties for repeated violations.

\section{Leadership}

Drath and Palus in Gary Yukl (2015: 3) state that: Leadership is the process of understanding what people do together, so they understand and want to do it. According to Sutikno (2014: 16) Leadership in organizations is directed to influence the people they lead, so they are willing to act as expected or directed by others who lead them. Veithzal Rivai (2014: 3) argues that: Leadership is a behavior with a specific purpose to influence the activities of group members to achieve common goals that are designed to provide benefits to individuals and organizations, so that in an organization leadership is a very important factor in determining the achievement of goals predetermined by the organization. According to Hasibuan (2017: 170), leadership is the way a leader influences the behavior of subordinates, so they are willing to work together productively to achieve organizational goals.

Leadership Function

According to Rivai (2014: 34), namely:

1. Instruction function

This function is one-way communication, the leader as a communicator is the party that determines what, how, when, and where the order is done so that decisions can be implemented effectively. Effective leadership requires the ability to move and motivate others to want to carry out orders.

2. Consultation Function

This function is two-way communication. In the first stage of making decisions, leaders often need consideration, which requires them to consult with the people they lead who are judged to have a variety of information material needed in setting decisions. The consultation was intended to obtain input in the form of feedback (feed back) to improve and perfect decisions that have been determined and implemented.

3. Participatory Function

In carrying out this function the leader tries to activate the people he leads, both in participating in making decisions and in implementing them. Participation does not mean free to do as you wish, but it is carried out in a controlled and tedious form of cooperation by not interfering or taking on other people's basic tasks.

\section{Supervision}

According to Siagian (2014: 125), states that supervision is the process of observation of all organizational activities in order to better ensure that all work being carried out is in accordance with a predetermined plan. According to Robbin (2012: 150), states that supervision is a very basic activity process, so it requires a manager to carry out the tasks and work of the organization. According to Handoko (2016: 359), Oversight helps assess whether planning, organizing, preparing personnel, and directing has been carried out effectively. leadership is affecting other people, subordinates or groups, the ability to direct the behavior of subordinates or groups, has the 
ability or special expertise in the field desired by the group, to achieve organizational or group goals ( Sutrisno Mustafidah 2019:65).

\section{Punishment}

According to Mangkunegara (2015: 130), Punishment is a threat of punishment aimed at improving the performance of violating employees, maintaining applicable regulations and giving lessons to violators. According to Rivai (2014: 444), Punishment is also interpreted as a tool used by leaders to communicate with employees so that they are willing to change a behavior and as an effort to increase one's awareness and availability in compliance with all company regulations and applicable social norms.

\section{Conceptual Framework}

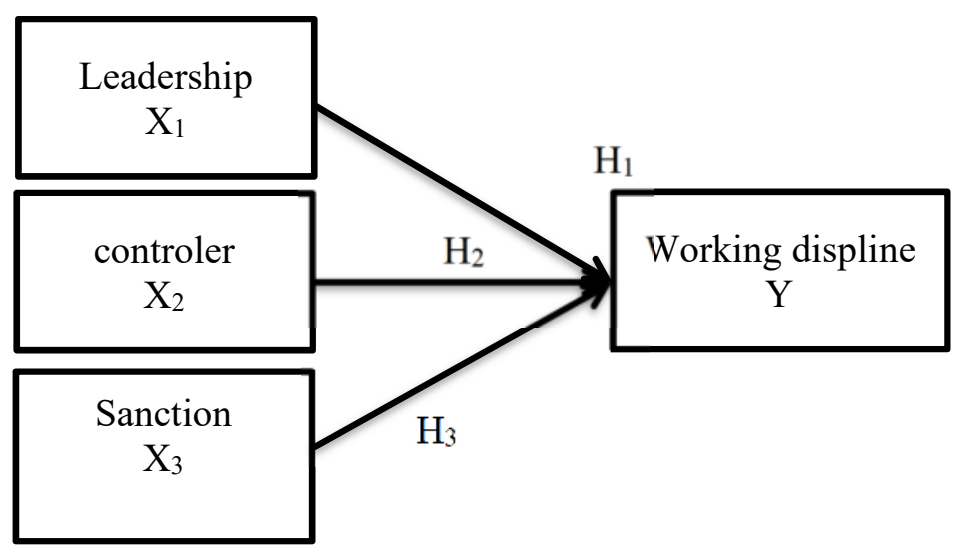

\section{Hypothesis Development}

Research conducted by Reni Puspita Sari (2015), found that leadership has a positive and significant (significant) effect on discipline. Similar results can also be seen from other studies conducted by Febri Setiyani (2015), showing that Leadership and Supervision have a positive and significant effect on work discipline. H1: Leadership influences Employee Work Discipline.

Research conducted by Reni Puspita Sari (2015) found the results that supervision had a positive and significant (significant) effect on discipline.

H2: Supervision affects employee Work Discipline

Faizal Hidayat's research (2018), states that there is an influence between sanctions and work discipline H3: Punishment affects Employee Work Discipline

\section{RESEARCH METHODOLOGY}

This research is causal research, where this research aims to find out the cause and effect between several variables or strategies developed in management. This study is to illustrate the existence of a causal relationship between situations described in variables and a general conclusion is drawn.

Research Population

According to Sugiyono (2015), population is a generalization area consisting of: objects / subjects that have certain qualities and characteristics that are determined by research to be studied and then conclusions drawn. In this study the population is 100 employees in PT Kharisma Berkah Intikarsa.

Research Samples

According to Sugiyono (2015), the sample is part of the number and characteristics possessed by the population. The sample was conducted because of the limitations of researchers in conducting research both in terms of time, energy, and a very large population. In this study using Probability sampling technique. Number of samples $(n)=$ 80 employees.

Method of collecting data

This study uses primary data is data obtained directly from the object under study. Primary data collection is done by conducting a survey directly to PT. Kharisma Berkah Intikarsa as research object. The purpose of this field research is to obtain accurate data. The data obtained by means of research include: 
a. Observation, which is doing a direct observation of the place that is used as the object of research where the object of this research is located at PT. Charisma Blessing Initiative.

b. Questionnaire (questionnaire), questionnaire is a data collection technique that is done by giving a set of questions or written statements to respondents to be answered (Sugiyono, 2015). The method of collecting questionnaires in this study is to use the method of personally administrated qustonnnaries, which means that researchers submit questionnaires themselves to respondents and take the questionnaires that have been filled out by respondents. The reason the researcher used the method was to improve the return of the questionnaire in a relatively short time. In this study primary data were obtained by distributing questionnaires distributed to samples that have been determined at PT. Charisma Blessing Initiative.

\section{DISCUSSION}

\section{Data Validity Test}

According to Sugiyono (2015: 121) said that the results of the study were valid if there were similarities between the data collected and the data that actually happened to the object under study.

Validity test is used to measure the degree of accuracy in each item statement of a questionnaire, the statements in the questionnaire can be said to be valid if the statement is able to reveal something that will be measured by the questionnaire and if the calculated correlation value ( $\mathrm{r}$ count) is greater than the correlation value in the table ( $\mathrm{r}$ table). The calculated $r$ values are the values that are in the "correlations" column on the spss output sheet.

Significant test is done by comparing the value of $r$ count with $r$ table for degree of freefdom $(\mathrm{df})=\mathrm{n}-4$ in this $\mathrm{n}$ is the number of samples. So the df used is $80-4=76$ with alpha of $5 \%$, resulting in a table $\mathrm{r}$ value (twotailed test) of 0.222

Leadership Variable Test Results

From the data processing, the results are as shown in the following table:

Validity test leadership $\left(\mathbf{X}_{1}\right)$

\begin{tabular}{lllll}
\hline No & Subject & r-test & r-Tabel & Remarks \\
\hline 1 & Item 1 & 0,496 & 0,222 & Valid \\
\hline 2 & Item 2 & 0,595 & 0,222 & Valid \\
\hline 3 & Item 3 & 0,694 & 0,222 & Valid \\
\hline 4 & Item 4 & 0,431 & 0,222 & Valid \\
\hline 5 & Item 5 & 0,687 & 0,222 & Valid \\
\hline 6 & Item 6 & 0,533 & 0,222 & Valid \\
\hline 7 & Item 7 & 0,623 & 0,222 & Valid \\
\hline 8 & Item 8 & 0,557 & 0,222 & Valid \\
\hline 9 & Item 9 & 0,691 & 0,222 & Valid \\
\hline 10 & Item 10 & 0,623 & 0,222 & Valid \\
\hline
\end{tabular}

Based on the table above, it appears that all $\mathrm{r}$-counts are greater than $\mathrm{r}$-tables for all statement items. This means that all the criteria used in the Leadership variable are considered valid.

Monitoring Variable Validity Test Results

From the data processing, the results are as shown in the following table:

Validity test Control $\left(\mathrm{X}_{2}\right)$

\begin{tabular}{lllll}
\hline No & Subject & r-test & r-Tabel & Remarks \\
\hline 1 & Item 1 & 0,712 & 0,222 & Valid \\
\hline 2 & Item 2 & 0,468 & 0,222 & Valid \\
\hline 3 & Item 3 & 0,640 & 0,222 & Valid \\
\hline 4 & Item 4 & 0,504 & 0,222 & Valid \\
\hline 5 & Item 5 & 0,630 & 0,222 & Valid \\
\hline 6 & Item 6 & 0,634 & 0,222 & Valid \\
\hline 7 & Item 7 & 0,571 & 0,222 & Valid \\
\hline 8 & Item 8 & 0,480 & 0,222 & Valid \\
\hline 9 & Item 9 & 0,525 & 0,222 & Valid \\
\hline 10 & Item 10 & 0,783 & 0,222 & Valid \\
\hline
\end{tabular}


Based on the table above it can be seen that the entire r-count is greater than the r-table for all statement items. This shows that all criteria used in the monitoring variable are considered valid.

Punishment Variable Validity Test Results

From the data processing, the results are as shown in the following table:

Validity test Variabel Punishment $\left(\mathrm{X}_{3}\right)$

\begin{tabular}{lllll}
\hline No & subject & r-test & r-Tabel & remarks \\
\hline 1 & Item 1 & 0,455 & 0,222 & Valid \\
\hline 2 & Item 2 & 0,653 & 0,222 & Valid \\
\hline 3 & Item 3 & 0,649 & 0,222 & Valid \\
\hline 4 & Item 4 & 0,723 & 0,222 & Valid \\
\hline 5 & Item 5 & 0,376 & 0,222 & Valid \\
\hline 7 & Item 6 & 0,578 & 0,222 & Valid \\
\hline 8 & Item 7 & 0,508 & 0,222 & Valid \\
\hline 9 & Item 8 & 0,561 & 0,222 & Valid \\
\hline 10 & Item 9 & 0,533 & 0,222 & Valid \\
\hline
\end{tabular}

Based on the table above it can be seen that the entire r-count is greater than the r-table for all statement items. This shows that all criteria used in the punishment variable are considered valid.

Work Discipline Variable Validity Test Results

From the data processing, the results are as shown in the following table:

\begin{tabular}{lllll}
\multicolumn{6}{l}{ Validity test working discipline $(\mathbf{Y})$} \\
\hline No & subject & r-test & r-Tabel & Remarks \\
\hline 1 & Item 1 & 0,502 & 0,222 & Valid \\
\hline 2 & Item 2 & 0,550 & 0,222 & Valid \\
\hline 3 & Item 3 & 0,712 & 0,222 & Valid \\
\hline 4 & Item 4 & 0,624 & 0,222 & Valid \\
\hline 5 & Item 5 & 0,663 & 0,222 & Valid \\
\hline 6 & Item 6 & 0,717 & 0,222 & Valid \\
\hline 7 & Item 7 & 0,726 & 0,222 & Valid \\
\hline 8 & Item 8 & 0,593 & 0,222 & Valid \\
\hline 9 & Item 9 & 0,712 & 0,222 & Valid \\
\hline 10 & Item 10 & 0,278 & 0,222 & Valid
\end{tabular}

Based on the table above it can be seen that the entire r-count is greater than the r-table for all statement items. This shows that all criteria used in work discipline variables are considered valid

\section{Classic assumption test}

Normality test

The normality test is useful for testing whether in the regression model, the dependent variable and the independent variable have a normal distribution. The normality test is carried out on the basis of the Kolmogorov Smirnov (KS) test with p 2 sides (two tailed) with the criteria used is if the results of the calculation of KS with 2 sides are greater than 0.05 then the data is normally distributed (Sugiyono 2015: 323).

In the Kolmogorov Smirnov Test study, decision making on the Kolmogorov Smirnov test obtained Sig values.

- If the Prob./Sig F value is $>5 \%$, then the distribution is normal.

- If the Prob./Sig F value is $<5 \%$, then the distribution is abnormal. 


\section{One-Sample Kolmogorov-Smirnov Test}

\begin{tabular}{lll}
\hline & & Unstandardized Residual \\
\hline $\mathrm{N}$ & & 80 \\
\hline \multirow{2}{*}{ Normal Parameters ${ }^{\mathrm{a}, \mathrm{b}}$} & Mean & 0.0000 \\
\cline { 2 - 3 } & Std. Deviation & 1,89906871 \\
\hline \multirow{2}{*}{ Most Extreme Differences } & Absolute & 0,067 \\
\cline { 2 - 3 } & Positive & 0,08 \\
\cline { 2 - 3 } & Negative & $-0,067$ \\
\hline Kolmogorov-Smirnov Z & & 0,327 \\
\hline Asymp. Sig. (2-tailed) & & 0,769 \\
\hline
\end{tabular}

a. Test distribution is Normal.

b. Calculated from data.

The table above shows that the Asymp value. Sig. (2-tailed) obtained at $0.769>0.05$ means that the data is normally distributed.

\section{Multicollinearity Test}

Multicollinity is a state between two or more independent variables in a regression model where perfect or near perfect linear relationships occur. A good regression model requires the absence of multicollinearity, Ghozali (2013: 105). The purpose of the Multicollinearity test is to test whether the regression model found a correlation between independent variables. Multicollinearity test can be detected by calculating multiple coefficients and comparing them with the correlation coefficient between independent variables with the base value of VIF (Variant Inflation Factor). The criterion used is if the VIF value $<10$ and has a tolerance exceeding 0.1 , then it can be said there is no Multicollinearity problem

\begin{tabular}{|c|c|c|c|}
\hline \multicolumn{4}{|c|}{ Coefficients $^{\mathrm{a}}$} \\
\hline \multirow{2}{*}{\multicolumn{2}{|c|}{ Model }} & \multicolumn{2}{|c|}{ Collinearity Statistics } \\
\hline & & Tolerance & VIF \\
\hline \multirow{4}{*}{1} & (Cons & & \\
\hline & $\mathrm{T} \mathrm{X}_{1}$ & 0,203 & 4,916 \\
\hline & $T \_X_{2}$ & 0,118 & 8,506 \\
\hline & $\mathrm{T} \mathrm{X}_{3}$ & 0,180 & 5,559 \\
\hline
\end{tabular}

a. Dependent Variable: $\mathrm{Y}$

The table above shows the Leadership variable (X1) obtains tolerance value, $0.203>0.10$ and VIF $4.916<10$, Monitoring Variable (X2) obtains tolerance value, $0.118>0.10$ and VIF $8.506<10$, Punishment Variable (X3) obtains value $0.180>0.10$ and VIF $5.559<10$, there is no Multicollinearity among the independent variables.

\section{Heteroskedaticity Test}

Heteroscedasticity test aims to test whether the regression model occurs Variance inequality from residuals of one observation to another. If the variance from one observation residual to another observation is fixed, then it is called Homoscedasticity and if different is called Heteroscedasticity. A good regression model is Homoscedasticity or Heteroskesdasticity does not occur. To detect the presence or absence of heteroskesdastisitas can be done by using a Scatterplot chart. (Ghozali, 2013: 139). As a basis for the analysis as follows:

a. If certain patterns, such as dots, form a regular pattern (wavy, widened and then narrowed), then it indicates that heteroscedasticity has occurred.

b. If there is no clear pattern, and the points spread above and below the number 0 on the $\mathrm{Y}$ axis, then there is no heteroscedasticity. 


\begin{tabular}{|c|c|c|c|c|c|c|}
\hline \multicolumn{7}{|c|}{ Coefficients $^{\mathrm{a}}$} \\
\hline \multirow{2}{*}{ Model } & & \multicolumn{2}{|c|}{$\begin{array}{l}\text { Unstandardized } \\
\text { Coefficients }\end{array}$} & \multirow{2}{*}{$\begin{array}{c}\begin{array}{c}\text { Standardized } \\
\text { Coefficients }\end{array} \\
\text { Beta }\end{array}$} & \multirow{2}{*}{$\mathrm{t}$} & \multirow{2}{*}{ Sig. } \\
\hline & & $\mathrm{B}$ & Std. Error & & & \\
\hline & (Constant) & 3.14 & 1.221 & & 2.571 & 0.012 \\
\hline & T_PGS & 0.044 & 0.082 & 0.178 & 0.544 & 0.588 \\
\hline & T_KP & -0.006 & 0.064 & -0.022 & -0.088 & 0.930 \\
\hline & $\mathrm{T}$ PNS & -0.086 & 0.068 & -0.334 & -1.26 & 0.211 \\
\hline
\end{tabular}

a. Dependent Variable: ABS RES

Based on the table above, it is known that the results of the Heteroscedasticity test indicate that the variables of Leadership (X1), Supervision (X2) and Punishment (X3) get a sig value $>0.05$, so there is no heteroscedasticity in the regression model, and is strengthened with the following Scatteplot graph:

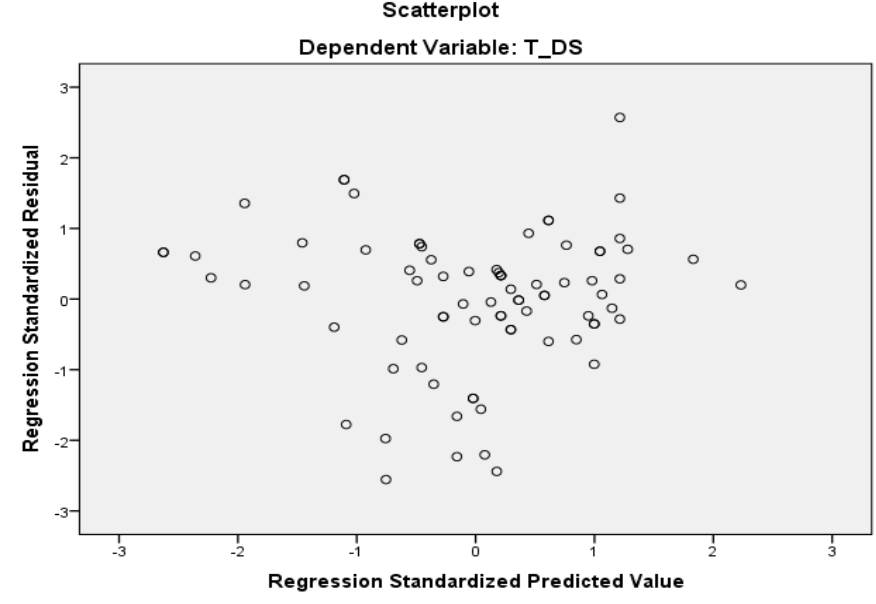

Based on the graph above, it can be seen that the points on the Scatterplot result are above the 0 (zero) line and below the 0 (zero) line. This does not occur heteroscedasticity.

\section{Determination Coefficient Test (R2)}

According to Ghozali (2013: 97) the coefficient of determination (R2) is a tool to measure how far the ability of the model in explaining the variation of the dependent variable. The coefficient of determination is between 0 (zero) and 1 (one). A small R2 value means that the ability of the independent variables to explain the variation of the dependent variable is very limited. And conversely if a value close to 1 means that the independent variables provide almost all the information needed to predict the dependent variables.

\section{Model Summary ${ }^{b}$}

\begin{tabular}{llllll}
\hline Model & $\mathrm{R}$ & R Square & Adjusted R Square & $\begin{array}{l}\text { Std. Error of the } \\
\text { Estimate }\end{array}$ & \\
\hline 1 &, $922^{\mathrm{a}}$ & 0,849 & 0,843 & 1,75126 & \\
\hline
\end{tabular}

a. Predictors: (Constant), T_X 3 , T_ $X_{2}, T_{-} X_{1}$

b. Dependent Variable: Y

R2 value of 0.843 or $84.3 \%$. This means that the variables of leadership, supervision and punishment provide an effect of $84.3 \%$ on employee work discipline. While the remaining $15.7 \%$ is influenced by other variables outside the research model. 


\section{Simultaneous Test (Statistical Test F)}

Statistical Test F is carried out to test simultaneously whether the independent variables (leadership, supervision, and punishment) have a significant influence on the dependent variable (work discipline). In this $F$ test using a significant level of $(\alpha=5 \%)$. The hypothesis model that will be used is as follows:

a. H0 = Leadership, Supervision, and Punishment simultaneously does not significantly influence Work Discipline.

b. H1 = Leadership, Supervision and Punishment significantly influence Work Discipline.

With decision making criteria if significance $<0.05$ then $\mathrm{H} 0$ is rejected and $\mathrm{H} 1$ is accepted, it means that there is a significant influence of the independent variables individually on the dependent variable. If it is significant> 0.05 then $\mathrm{H} 0$ is accepted and $\mathrm{H} 1$ is rejected, it means that there is no significant influence of the independent variables individually on the dependent variable

\begin{tabular}{|c|c|c|c|c|c|c|}
\hline \multicolumn{7}{|c|}{ ANOVA $^{\mathrm{a}}$} \\
\hline Model & & $\begin{array}{c}\text { Sum of } \\
\text { Squares }\end{array}$ & $\mathrm{df}$ & Mean Square & $\mathrm{F}$ & Sig. \\
\hline \multirow{3}{*}{1} & Regression & 1312,72 & 3 & 437,572 & 142,676 &, $000^{\mathrm{b}}$ \\
\hline & Residual & 233,084 & 76 & 3,067 & & \\
\hline & Total & 1545,8 & 79 & & & \\
\hline
\end{tabular}

a. Dependent Variable: T Y

b. Predictors: (Constant), T_ $\mathrm{X}_{3}, \mathrm{~T}_{-} \mathrm{X}_{2}, \mathrm{~T}_{-} \mathrm{X}_{1}$

Based on the table above shows that the results of the simultaneous hypothesis test or statistical test $\mathrm{F}$ produces an F-calculated value of 142.676 greater than the F-table of 2.4920 and a significant value of 0.000 less than 0.05 . This means that the regression analysis tool used in this study is feasible to use and can be used to predict the independent variables (leadership, supervision and punishment) of the dependent variable (work discipline).

\section{Multiple linear regression}

The multiple linear regression coefficient is used to determine the effect of the independent variable with the dependent variable. For regression where the independent variable consists of two or more, the regression is called multiple linear regression.

\section{Coefficients $^{\mathrm{a}}$}

\begin{tabular}{|c|c|c|c|c|c|c|}
\hline \multirow{2}{*}{\multicolumn{2}{|c|}{ Model }} & \multicolumn{2}{|c|}{ Unstandardized Coefficients } & \multirow{2}{*}{$\begin{array}{l}\text { Standardized } \\
\text { Coefficients } \\
\text { Beta }\end{array}$} & \multirow[t]{2}{*}{$\mathrm{t}$} & \multirow[t]{2}{*}{ Sig. } \\
\hline & & $\mathrm{B}$ & Std. Error & & & \\
\hline \multirow{4}{*}{1} & (Constant) & 0,346 & 1,889 & & 1,242 & 0,218 \\
\hline & $\mathrm{X}_{1}$ & 0,270 & 0,099 & 0,270 & 2,730 & 0,008 \\
\hline & $\mathrm{X}_{2}$ & 0,341 & 0,126 & 0,351 & 2,702 & 0,008 \\
\hline & $\mathrm{X}_{3}$ & 0,342 & 0,105 & 0,341 & 3,245 & 0,002 \\
\hline
\end{tabular}

a. Dependent Variable: Y

Based on the above table, the regression equation can be made as follows:

$$
\mathrm{Y}=0.270 \mathrm{X} 1+0.351 \mathrm{X} 2+0.341 \mathrm{X} 3
$$

The results of the regression equation on the significance of the coefficient and interpretation of the regression equation are as follows:

1. Leadership $(\mathrm{X} 1)=0.270$; which means that if there is an increase in the leadership variable, work discipline will increase.

2. Supervision $(\mathrm{X} 2)=0.351$; which means that if there is an increase in the Supervision variable, the work discipline will increase.

3. Punishment $(\mathrm{X} 3)=0.341$; which means that if the consistent application of the Punishment variable, work discipline will increase.

Partial Test (t Test Statistics)

$\mathrm{T}$ statistical test was conducted to partially test whether the independent variable had a significant effect on the dependent variable. In this test using a significant level of $(\alpha=5 \%)$. The hypothesis model that will be used is as follows:

a. $\mathrm{H} 0=$ The independent variable has no significant effect on the dependent variable

b. $\mathrm{H} 1=$ The independent variable influences the dependent variable. 
With decision making criteria, if significance $<0.05$ then $\mathrm{H} 0$ is rejected and $\mathrm{H} 1$ is accepted, if significance $>$ 0.05 then $\mathrm{H} 0$ is accepted and $\mathrm{H} 1$ is rejected.

\section{Significance Parameter Individual (Uji T)}

\begin{tabular}{|c|c|c|c|c|c|c|}
\hline \multirow{3}{*}{ Model } & & \multicolumn{3}{|c|}{ Coefficients $^{\mathrm{a}}$} & \multirow{3}{*}{$\mathrm{t}$} & \multirow{3}{*}{ Sig. } \\
\hline & & \multicolumn{2}{|c|}{$\begin{array}{l}\text { Unstandardized } \\
\text { Coefficients }\end{array}$} & \multirow{2}{*}{$\begin{array}{c}\begin{array}{c}\text { Standardized } \\
\text { Coefficients }\end{array} \\
\text { Beta }\end{array}$} & & \\
\hline & & B & Std. Error & & & \\
\hline \multirow{4}{*}{1} & (Constant) & 0,346 & 1,889 & & 1,242 & 0,218 \\
\hline & $\mathrm{X}_{1}$ & 0,270 & 0,099 & 0,270 & 2,730 & 0,008 \\
\hline & $X_{2}$ & 0,341 & 0,126 & 0,351 & 2,702 & 0,008 \\
\hline & $X_{3}$ & 0,342 & 0,105 & 0,341 & 3,245 & 0,002 \\
\hline
\end{tabular}

a. Dependent Variable: Y

Based on the table above the results of the hypothesis of the leadership variable (X1) produces a tcount of 2.730 greater than t table 1.9917 (with $\mathrm{df}=76$; alpha 0.05 ) and a significant value of 0.008 smaller than 0.05 . Thus, H0 is rejected and $\mathrm{H} 1$ is accepted, so it can be concluded that leadership has a positive effect on work discipline. For the monitoring variable (X2) produces a t-value of 2.702 is greater than $\mathrm{t}$ table 1.9917 (with $\mathrm{df}=76$; alpha 0.05 ) and a significant value of 0.008 , smaller than 0.05 . Thus, $\mathrm{H} 0$ is rejected and $\mathrm{H} 1$ is accepted, so it can be concluded that supervision has a positive effect on work discipline. For the punishment variable (X3) produces a t-value of 3.245 greater than t table 1.9917 (with $\mathrm{df}=76$; alpha 0.05 ) and a significant value of 0.002 , smaller than 0.05 . Thus, $\mathrm{H} 0$ is rejected and $\mathrm{H} 1$ is accepted, so it can be concluded that punishment has a positive effect on work discipline.

\section{Research result}

\section{Leadership Variables Against Work Discipline}

Based on data processing through the distribution of questionnaires given a sample, the researchers saw a very positive and significant leadership influence on the work discipline of PT. Kharisma Berkah Intikarsa Bekasi, West Java, it can be seen that the t-value of 2.730 is greater than the table 1.9917 with a significant level of 0.008 less than 0.05 . This means that the leadership is getting stronger the work discipline will experience a significant increase with the assumption that the other independent variables of multiple linear regression are fixed.

The results of this study are in line with the results of Kamal's (2015) study entitled The Effect of Leadership and Supervision on Employee Work Discipline at PT. Perkebunan Nusantara III (Persero), with the results of leadership research having a positive and significant effect on the work discipline of the employees of PT. Perkebunan Nusantara III (Persero). Permatasari (2015) with the title Analysis of the Effect of Leadership, Supervision, and Imposition of Sanctions on Employee Work Discipline (Study at PT. Citra Yoviana Semarang Branch) ", with the results of leadership research having a positive and significant effect on employee work discipline of PT. Citra Yoviana Semarang Branch.

\section{Variable Supervision of Work Discipline}

Based on data processing through the distribution of questionnaires provided samples, researchers see the effect of positive and significant compensation to the performance of employees of PT. Kharisma Berkah Intikarsa Bekasi, West Java. This can be seen with the results of the tcount of 2.703 greater than t table 1.9917 with a significant level of significance value of 0.008 , smaller than 0.05 . This means that the increase in supervision, work discipline will increase positively and significantly with the assumption that the other independent variables of multiple linear regression remain. The results of this study are in line with the results of the study of Setiyani (2015) with the title "The Effect of Leadership, and Supervision, Against the Security Work Discipline of PT. Karya Satria Abadi Pekanbaru "and the results of his surveillance research have a positive and significant effect on the work discipline of PT. Karya Satria Abadi Pekanbaru. Research by Havany (2016) with the title Influence of Leadership and Supervision Style on Work Disciplines of SPG Pamella Supermarket Yogyakarta branches one and three "with the results of surveillance research has a positive effect on SPG Pamella Supermarket Yogyakarta branches one and three. 


\section{Variable Punishment Against Work Discipline}

Based on data processing through the distribution of questionnaires provided samples, researchers see the influence of a positive and significant punishment on the work discipline of employees of PT. Kharisma Berkah Intikarsa Bekasi, West Java. This can be seen with the results of the tcount of 3.245 greater than t table 1.9917 with a significant level. Significant value of 0.002 , smaller than 0.05 . With the consistent application of punishment, employee work discipline will increase significantly with the assumption that the other independent variables of multiple linear regression remain. The results of this study are in line with the results of research from Hidayat (2018) with the title Effect of Reward and Punishment on Employee Performance with Work Discipline as an Intervening Variable in Waroeng Special Sambal Yogyakarta ", the results of the Punishment research affect the work discipline of Waroeng Special Sambal Yogyakarta employees. But the results of this study are not in line with research from Dunija (2016) with the title Effect of Reward and Punishment systems on Increasing Employee Work Discipline of PT. Tunggal Perkasa Plan-3 Aceh Jaya, the results of the punishment study did not have a significant effect on improving the work discipline of the employees of PT. Tunggal Perkasa Plan-3 Aceh Jaya.

\section{E. CONCLUSION}

Leadership has positive and significant influence on the Work Discipline of PT. Kharisma Berkah Intikarsa Bekasi West Java, meaning that strong leadership is needed by employees, to be an example where leadership shows work discipline. With leadership that sets an example for employees, employee discipline will increase

Supervision has a positive and significant effect on the work discipline of PT. Kharisma Berkah Intikarsa Bekasi, West Java, meaning that good supervision will increase employee work discipline

Punishment has a positive and significant effect on the work discipline of PT. Kharisma Berkah Intikarsa Bekasi, West Java, meaning that if punishment is carried out consistently, work discipline will increase.

\section{Suggestion}

Leadership (X1)

Based on the results of research on the leader indicator gives confidence to subordinates to be the highest average value, suggestions for the company, so that the company continues to maintain by giving confidence to subordinates completing work without any intervention, while indicators with the lowest value of leaders who do not provide guidelines in work, advice for companies so that there are improvements by providing guidelines to employees to do work with clear guidelines, so that the work is in accordance with company quality.

Supervision (X2)

Based on the results of research with the highest average value with indicators following procedures, suggestions for the company to continue to maintain and improve work procedures, while for indicators unable to complete work within the stipulated time, suggestions for the company, so the company can see the obstacles faced by employees in completing work, and providing solutions, so that work is completed.

Punishment (X3)

Based on the results of research with the highest average value indicators get a warning every violation, suggestions for companies to continue to maintain warning rules for employees who violate so that employees do not repeat their actions, while for the prohibition indicator applies to all employees become indicators with the lowest average value, a suggestion for the company not to see the position in the prohibition of doing something, so that other employees do not feel that the company prefers employees so that discipline can be enforced at work.

\section{References}

Andarias Kuddy. (2017). Pengaruh Kepemimpinan, Motivasi, dan Disiplin kerja Terhadap Kinerja Pegawai Pada Dinas Pertanian dan Ketahanan Pangan Provinsi Papua. Jurnal Manajemen dan Bisnis

Febri Setiyani (2015). Pengaruh Kepemimpinan, dan Pengawasan, Terhadap Disiplin Kerja Security PT. Karya Satria Abadi Pekanbaru. Universitas Riau Pekan Baru.

Ghozali, I. (2016). Aplikasi Analisis Multivariate Dengan Program SPSS, Cetakan Keempat. Semarang: Badan Penerbit Universitas Diponegoro.

Ghozali, I. (2013). Aplikasi Analisis Multivariate Dengan Program SPSS, Edisi Tujuh. Semarang: Badan Penerbit Universitas Diponegoro.

Handoko, Hani. (2016). Manajemen Personalia dan Sumber Daya Manusia, Edisi Revisi. Yogyakarta: BPFE Universitas Gadjah Mada.

Hasibuan, M. (2017). Manajemen Sumber Daya Manusia, Edisi Revisi. Jakarta: PT Bumi Aksara.

Hafied H, (2016). Manajemen Sumber Daya Manusia. Makassar: Kretakupa Print.

Ike Susanti (2017). Pengaruh Disiplin Kerja, Pengawasan dan Motivasi Terhadap Kinerja karyaawan di PT.MMW di Sidoarjo. Universitas Lamongan. 
Jaiz, Muhamad. (2012). Analisis Faktor Yang Mempengaruhi Kedisiplinan Kerja Guru (Studi Kasus Pada Sekolah Binaan), Volume 2, No. 2.

Jamil T, (2015). "The Impacts of Discipline, Motivation and Leadership in Makassar Lantamal Vi Office Indonesia. Academy Journal Of Interdiciplinary Studies.

Mangkunegara, AP. (2015). Manejemen Sumber Daya Manusia, edisi revisi. Bandung: PT Remaja Rosdakarya Offset.

M. Basri (2015). Pengaruh Kepemimpinan dan Pengawasan Terhadap Disiplin Kerja Karyawan pada PT. Perkebunan Nusantara III (Persero). Universitas Muhammadiyah Sumatera Utara.

Manda Lintang Havany (2016). Pengaruh Gaya Kepemimpinan dan Pemgawasan Terhadap Disiplin Kerja SPG Pamella Supermarket Yogyakarta cabang satu dan tiga. Universitas Negeri Yogyakarta.

Meisy Suwuh (2016). The Influence of Leadership style, Motivation, and Work Discipline on Employee Preformance at Bank SULUT KCP LIKUPANG. Sam Ratulangi University Manado

Purwanto, Ngalim. (2015). Psikologi Pendidikan. Bandung edisi revisi: PT. Remaja Rosdakarya.

Permatasari (2015). Analisis Pengaruh Kepemimpinan, Pengawasan, dan Pemberian Sanksi Terhadap Disiplin kerja karyawan (Studi pada PT. Citra Yoviana Cabang Semarang). Universitas Diponegoro.

Priansa DJ (2017). Manajemen kinerja pegawai. Bandung : Alfabeta.

Rivai, Veithzal dan Jauvani, Ella. (2014). Manajemen Sumber Daya Manusia untuk Perusahaan dari Teori ke Praktik. Jakarta: PT Rajagrafindo Persada.

Reni Puspita Sari (2015). Pengaruh Kepemimpinan dan Pengawasan Terhadap Disiplin Kerja Karyawan Pada PT. Karya Tama Bakti Mulia Kabupaten Kampar. Universitas Riau Pekan Baru.

Raymond Suak (2017). Pengaruh Reward dan Punishment Terhadap Kinerja Karyawan SutanRaja Hotel Amurang. Universitas Sam Ratulangi Manado

Siagian, Sondang P. (2014). Manajemen Sumber Daya Manusia. Jakarta : PT. Bumi Aksara.

Sugiyono. (2015). Metode Penelitian Pendidikan Pendekatan Kuantitatif, Kualitatif dan R\&D. Bandung: Alfabeta.

Suryani, \& Hendryadi. (2015). Metode Riset Kuantitatif: Teori dan Aplikasi pada Penelitian Bidang Manajemen dan Ekonomi Islam, Edisi pertama. Jakarta: Prenadamedia Group.

Sutrisno Mustafidah Atik Pengaruh Gaya Kepemimpinan Direktif Dan Disiplin Kerja Terhadap Kinerja Karyawan Jurnal Ilmiah Manajemen Dan Bisnis Vo. 5, no. 12019 Fakultas Ekonomi Dan Bisnis Universitas Mercu Buana Jakarta

Teuku Dunija (2016). Pengaruh sistem Reward dan Punishment Terhadap Peningkatan Disipin Kerja Karyawan PT. Tunggal Perkasa Plan-3 Aceh Jaya. Universitas Serambi Mekkah

Valensia Angelina Wisti Dapu (2015). The Iinfluence of Work Discipline, Leadership, and Motivation on Employee Performance at PT. Trakindo Utama Manado. University os Sam Ratulangi Manado

Wibowo (2016). Manajemen Kinerja. Edisi Kelima. Jakarta : Rajawali Pers. 